\title{
Airblast and Ground Vibration Monitoring at Chimiwungo Pit
}

\author{
Eugie Kabwe, Yiming Wang \\ School of Civil and Environmental Engineering, University of Science and Technology Beijing, Beijing, China \\ Email: kabweeugie@yahoo.com
}

Received 20 December 2015; accepted 25 January 2016; published 28 January 2016

Copyright (C) 2016 by authors and Scientific Research Publishing Inc.

This work is licensed under the Creative Commons Attribution International License (CC BY).

http://creativecommons.org/licenses/by/4.0/

(c) (i) Open Access

\begin{abstract}
Impacts of airblast and vibrations arise from blasting, a dangerous activity if not designed and performed to standard. This paper evaluates airblast and ground vibration levels and its potential impact on the neighbouring communities. Two calibrated seismographs were used to monitor potential airblast and ground vibration generated from the blast at Chimiwungo Pit. The blast complied with the set limits for infrastructures and slopes monitoring. Vibrations recorded from the trial shot PPV were predicted at $2.46 \mathrm{~mm} / \mathrm{s}$ and Airblast of $10 \mathrm{~mm} / \mathrm{s}$ with a maximum of $134 \mathrm{~dB}$ at the mine boundary, all remained well below accepted industry standards and guidelines. The airblast and ground vibration levels monitored and recorded were considered to be normal for surface blasting operations and had no negative impact on the nearby township of Manyama.
\end{abstract}

\section{Keywords}

Airblast, Blasting, Chimiwungo Pit, Seismographs, Vibration

\section{Introduction}

Operations in mines that involve blasting, are regularly accompanied by seismic effects and they include, vibrations, air-blast, fly rock, fumes and dust. Improper planning, design and field working errors of blasts as well as erratic site conditions, inconsistency of rock mass properties and features of explosives and accessories may cause a negative impact in the locality of a blasting operation [1]. Ground vibration and air-blast both have negative impact, as they cause damage to the surface structures and nuisance to the neighbouring communities of the mine, while, fly rock is likely to endanger assets and human life [2]. Air and ground vibration from blasting is an unwanted side effect of explosive utilisation for excavation. The actual damage measure of ground vibration is the Peak Particle Velocity (PPV) of the conducting ground medium or wave acceleration [3] [4]. The quaking of building and other constructions is also directly and linearly proportional to ground vibration ampli- 
tude. If the PPV is reduced by half, structural response will be cut in half [4] [5]. In a larger blast it's impossible to completely avoid the superposition and amplification of the vibrations. This is because the period of the vibration is always significantly higher than the effective delays used between the charges in smaller blasts [6].

The potential air-blast and vibration impacts related with the Chimiwungo open pit of Lumwana mine are typical for a large open-pit mining operation and generally include:

- Operation of light and heavy vehicles for transportation of personnel, materials and equipment within the site.

- Drilling and blasting operations inside the site, to support excavations of the open pits.

- Operation of movable and motionless motorized equipment within the area limit, includes haul trucks, excavators, bulldozers, loaders, drill rigs, aggregate crushers and conveyor systems.

- Operations like gyratory crushers, grinding mills, separators, and conveyors in the processing plant.

- Periodic operation of countless acoustic safety signals, alarms or sirens [7].

The major impacts of vibrations arising from blasting operations had attracted attention by community members in Manyama Township, raised a number of complaints with regard to cracking of houses allegedly caused by blasting at the chimiwungo pits, despite the fact that the township is $2000 \mathrm{~m}$ from the blast zones [8]. Receptors for mining related air-blast and vibration were 1) mining workforce, personnel in the Lumwana Township, 2) the human population living in the Manyama area. Basically the local communities living in the Manyama area were the main source of complaints on blast vibration and air-blast impacts. The most affected were those living on the side of the T5 highway from Solwezi to Mwinilunga [8]. The study was designed with the following objectives

1) To investigate the side effects of blasting.

2) Measurements of blast induced vibration, airblast level in and around the mine generated due to blasting.

3) Estimate safe charge and simulation to determine maximum number of holes firing per delay.

4) To suggest airblast and ground vibration levels was within safe limits from the shot blasted.

\section{Location and Geology of Study Area}

The Lumwana copper project is situated in the Northwest Province of Zambia, roughly $65 \mathrm{~km}$ west of the provincial capital of Solwezi, $225 \mathrm{~km}$ west of Chingola a city in the Copperbelt and about $450 \mathrm{~km}$ northwest direction of Lusaka. The Lumwana area covers $1355 \mathrm{~km}^{2}$ and includes two major copper deposits, Malundwe and Chimiwungo, which make up the Lumwana Project (Figure 1) [9].

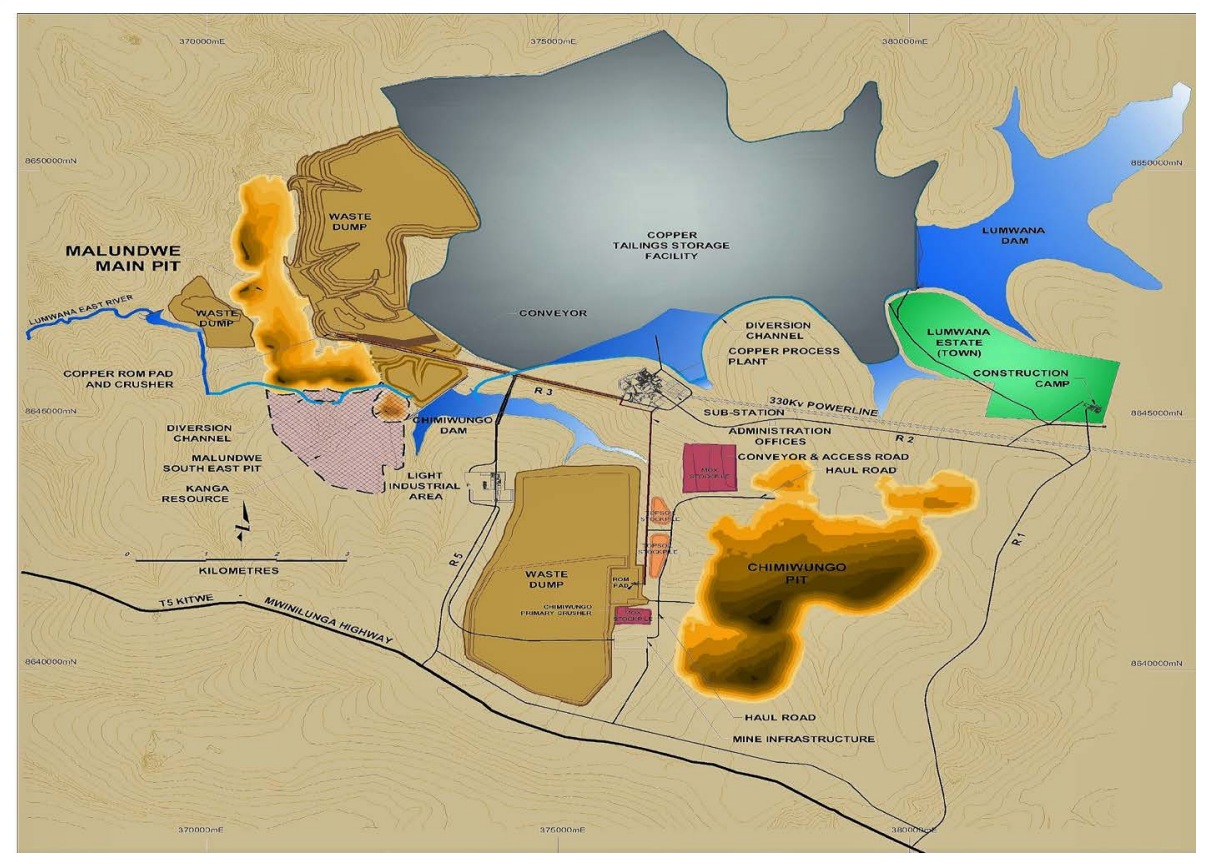

Figure 1. Lumwana project layout. 
The Lumwana copper, cobalt, gold, uranium deposits of Malundwe and Chimiwungo are held inside the Mwombezhi Dome, a bi-lobate basement dome in the western limb of the Neoproterozoic Lufilian Arc thrust fold belt, that trends northeast. This thrustfold belt comprises of a north directed arcuate array of void antiformal basement inliersor domes bounded by Katanganmeta sediments, which host the Central African Copperbelt, straddling across the Copperbelt and Northwest Provinces of Zambia and the Katangan Province of the Democratic Republic of Congo [10] [11]. In Zambia, the Lufilian Arc comprises erratically deformed and metamorphosed Late Proterozoicmeta sediments and volcanics of the Katangan Lower and Upper Roan, and the Lower and Upper Kundelungu Supergroups, unconformably overlying the Basement. The Basement comprises of older metamorphosed gneisses, schists, migmatites, amphibolites and granitoids. Successive to the deposition of the Katangan categorisations the basin was inverted, deformed, metamorphosed and uplifted by mostly north directed thrusting and folding creating the late Neoproteozoic Lufilian Arc [10] [11].

\section{Methodology}

Materials used for the study included two calibrated seismographs (2317 and 831), these were used to monitor potential air blast and ground vibration components generated from the blast (Figure 2), these components were monitored to estimate the site specific attenuation factors. Charge quantities per delay were observed and recorded, type of blast undertaken was bench blasting, blast and drill pattern where observed and no change was made. The AEL tie up software was used to time blast pattern, further computer simulation for hole fired pay delay was conducted. Vibrations were measured on the ground surface with the aid of a blast monitor, only one blast shot was monitored (CS1_1316_B48) at Chimiwungo Pit. Lumwana mine adopted a three way approach to checking vibration readings. All readings below $5 \mathrm{~mm} / \mathrm{sec}$ PPV are considered acceptable. Readings between 5 and $12.7 \mathrm{~mm} / \mathrm{sec}$ PPV are considered marginal. They are checked against the frequency readings to make sure they do not cross the threshold at the low frequency range (between 0 and $3 \mathrm{~Hz}$ ) [12]. Limits have been set for unreasonable air-blast from the very short-term audible blast at $94 \mathrm{~dB}$ and $98 \mathrm{~dB}$.

\subsection{Instrument Set-Up}

Each instrument was set to the trigger level in order for it to trigger and start recording for vibration and air blast amplitudes above the levels that it's set. It was important not to make the instrument too sensitive and end up recording noise caused by unrelated events such as wind and blast sirens. Similarly, it wasn't made too insensitive as it would not trigger when the blast is fired (Table 1). Seismograph 831 was placed approximately $700 \mathrm{~m}$,
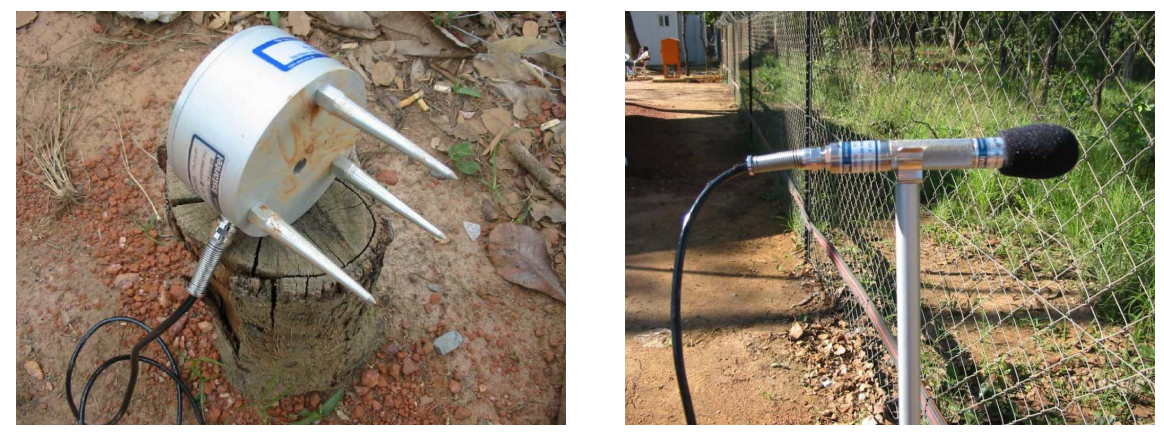

Figure 2. Parts of the calibrated seismographs.

Table 1. Parameters for seismographs.

\begin{tabular}{ccc}
\hline & \multicolumn{2}{c}{ Instrument } \\
\cline { 2 - 3 } Maximum PPV range & $127 \mathrm{~mm} / \mathrm{s}$ & $127 \mathrm{~mm} / \mathrm{s}$ \\
Maximum acoustic range & $148 \mathrm{~dB}$ & $148 \mathrm{~dB}$ \\
Recording/sample rate & 1024 & 1024 \\
PPV triggering & $3 \mathrm{~mm} / \mathrm{s}$ & $3 \mathrm{~mm} / \mathrm{s}$ \\
Acoustic triggering & $120 \mathrm{~dB}$ & $120 \mathrm{~dB}$ \\
\hline
\end{tabular}


whilst Seismograph 2317 was placed further at a distance approximately $1352 \mathrm{~m}$ from the blast. The area of concern was the Manyama Township which was at $\pm 2000 \mathrm{~m}$ from the pit. Instruments were positioned based on where the mine usually put their instruments (Figure 3).

\subsection{Blast Parameters}

A conventional blast using aggregate as stemming material was conducted on bench 1316 RL. Drilling and preparation of the blast shot was done to the required standard. Table 2 shows blast parameters of the conventional blast, the shot was charged and set for blasting (Figure 4).

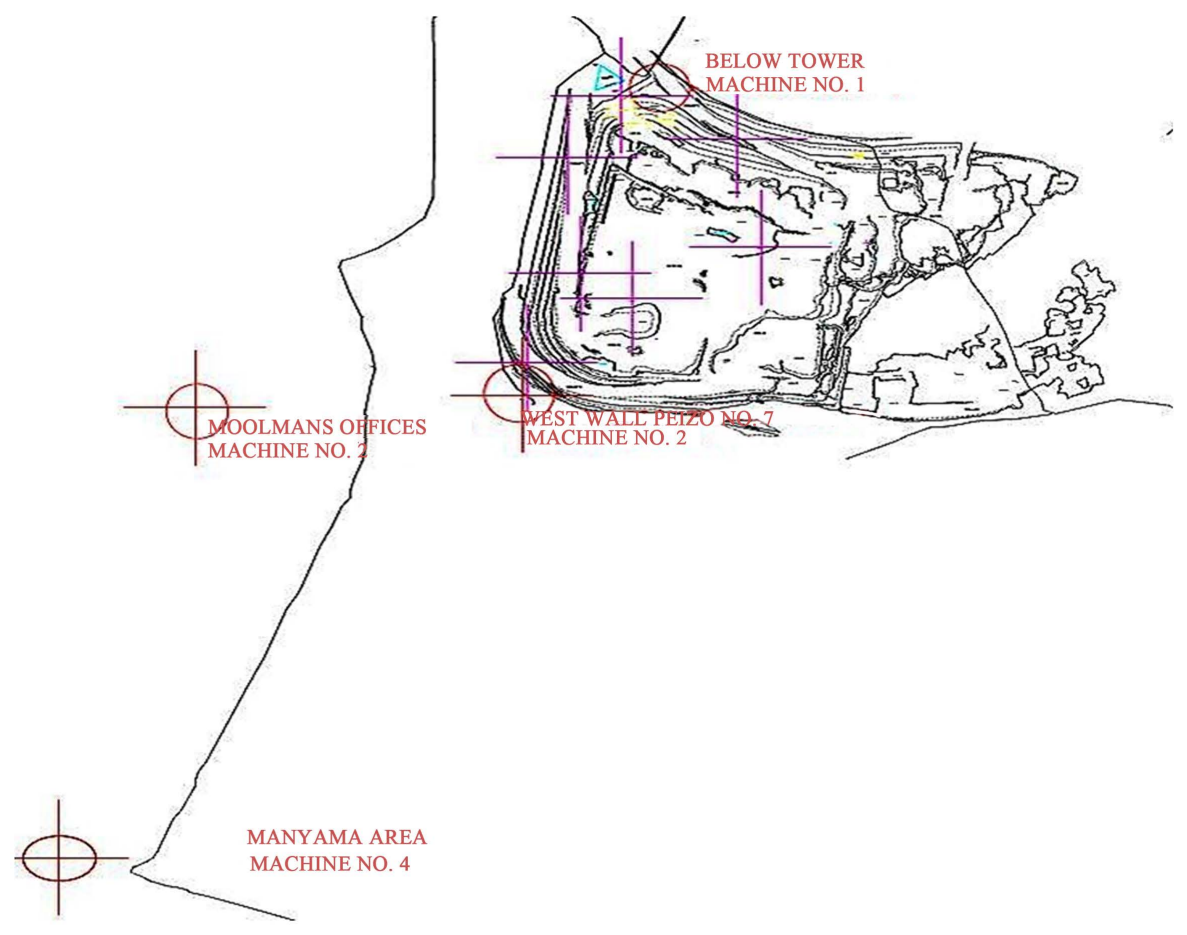

Figure 3. Positions of the instruments.

Table 2. Blast parameters.

\begin{tabular}{cccc}
\hline Description & \multicolumn{2}{c}{ Blast parameters } \\
\cline { 2 - 3 } Hole diameter & Units & 165 \\
Average hole depth & $\mathrm{mm}$ & 12.0 \\
Burden & $\mathrm{m}$ & 4.5 \\
Spacing & $\mathrm{m}$ & 4.7 \\
Stemming length & $\mathrm{m}$ & 3.5 \\
In-hole water level & $\mathrm{m}$ & 0 \\
& Drill pattern & Square \\
& Stemming material & Aggregate \\
& Explosive Type & SD 130 & 196 \\
Explosive Mass per hole (kg) @ Density 1.08 & Bottom charge-pumping \\
& Charging method & Shock tube \\
& Initiation system & 400 g Pentolite Primer \\
\hline
\end{tabular}




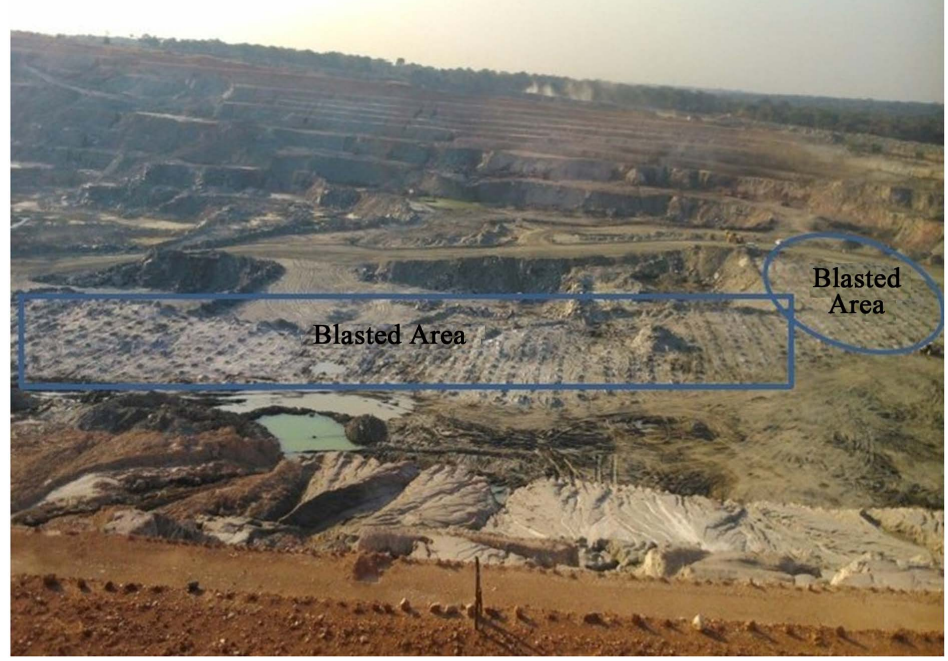

Figure 4. Blast shotthat was blasted.

\section{Experimentation}

\subsection{PPV Results}

Lumwana mine has adopted "best practise" standards for the African mining market based upon extensive research and measurements in the field across many mining types; this is backed up by International standards such as the United States Bureau of Mines, USBM. Table 3 shows the current AEL guidelines to ensure that any blasting vibrations generated are well below the minimum potential for damage.

Ground vibration levels recorded were found to be $4.527 \mathrm{~mm} / \mathrm{s}$. Table 4 shows seismograph results obtained from the shot. Seismograph 2317 which was positioned further at a distance of $\pm 1351 \mathrm{~m}$ away from the blast did not trigger due to the levels being lower than the set trigger of $3 \mathrm{~mm} / \mathrm{s}$. Figure 5 shows the blast vibration records.

The ground vibration levels obtained at approximately $700 \mathrm{~m}$ from the blast were found to be lower than 10 $\mathrm{mm} / \mathrm{s}$. Based on USBM suggested vibration level guidelines for buildings, the levels are well below the level of ground vibration to cause any concern to the surrounding township.

Using AEL Tie-up software, the blast timing pattern was analysed to determine the number of holes firing within a $8 \mathrm{~ms}$ time frame. A simulation based on the potential scatter for the shock tube product found that the nominal 8 holes could extend to a maximum of 12 holes per blast. Figure 6 shows a timing plan of the blast and the nominal number of holes firing per delay. The mass per delay was calculated and found to range from a nominal of $1568 \mathrm{~kg} /$ delay to a maximum of $2352 \mathrm{~kg} /$ delay. Simulation to determine maximum number of holes firing per delay is shown (Figure 7).

Using the USBM guidelines, the Peak Particle Velocity, PPV mm/s calculates out at a nominal $1.76 \mathrm{~mm} / \mathrm{s}$ or maximum of $2.46 \mathrm{~mm} / \mathrm{s}$ which are well below the normal background levels. The particle movement is measured to determine the magnitude of the blast vibration, maximum particle vibration can be estimated using the following formula (Equation (1) \& Equation (2)) [12] [14].

$$
P P V=K\left[\frac{R}{Q^{0.5}}\right]^{B}
$$

where:

$\mathrm{PPV}=$ peak particle velocity $(\mathrm{mm} / \mathrm{s})$;

$\mathrm{K}=$ site and rock factor constant;

$\mathrm{Q}=$ maximum instantaneous charge (kg);

$\mathrm{B}=$ constant related to the rock and site (usually -1.6 );

$\mathrm{R}=$ distance from charge $(\mathrm{m})$.

PPV recorded by machine, using the Cube root scaled distance is given by: 


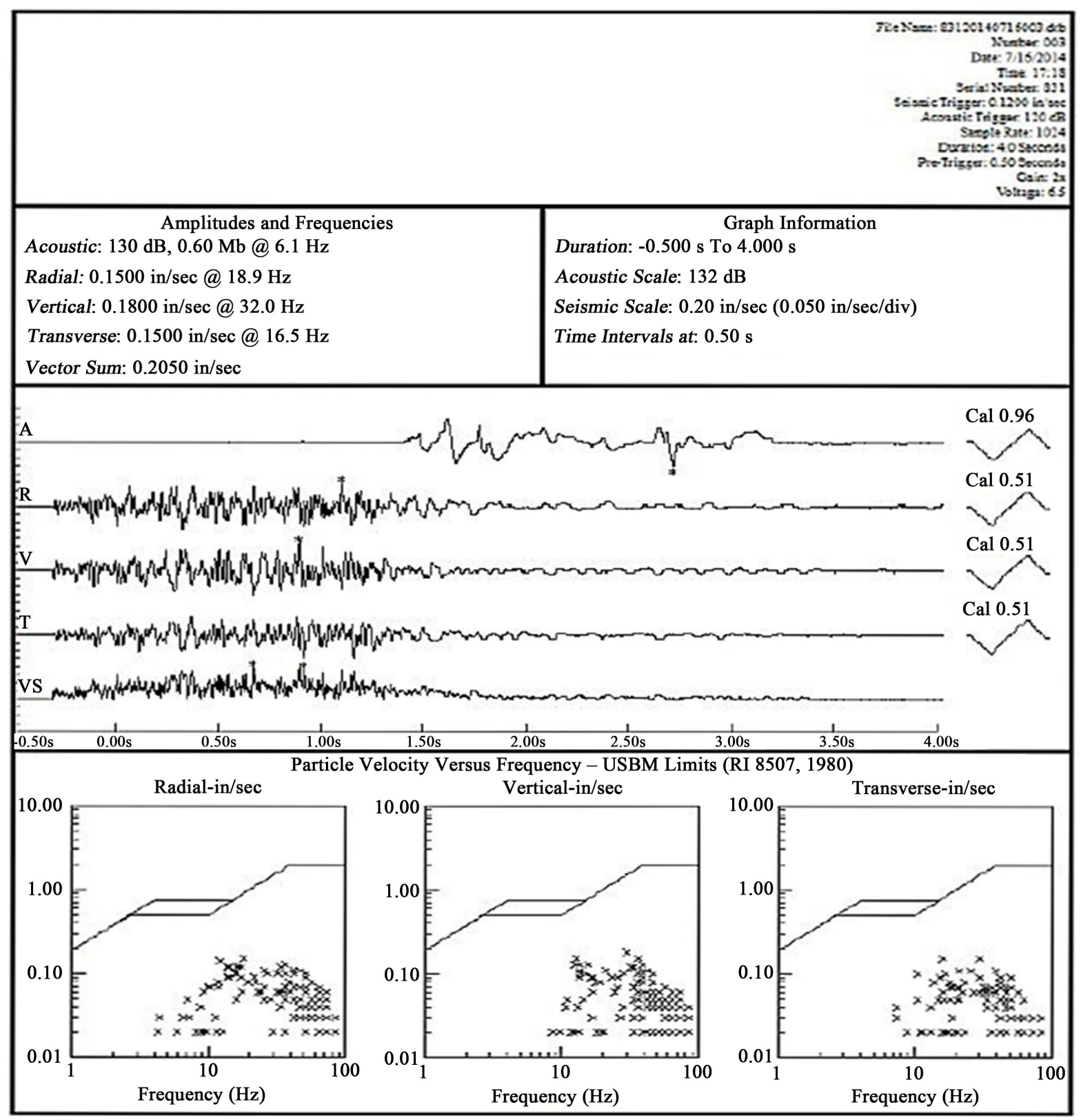

Figure 5. Blast vibration records.

Table 3. Guidelines on vibration levels [13].

Property owned by the concern performing blasting operations where minor plaster cracks are acceptable 


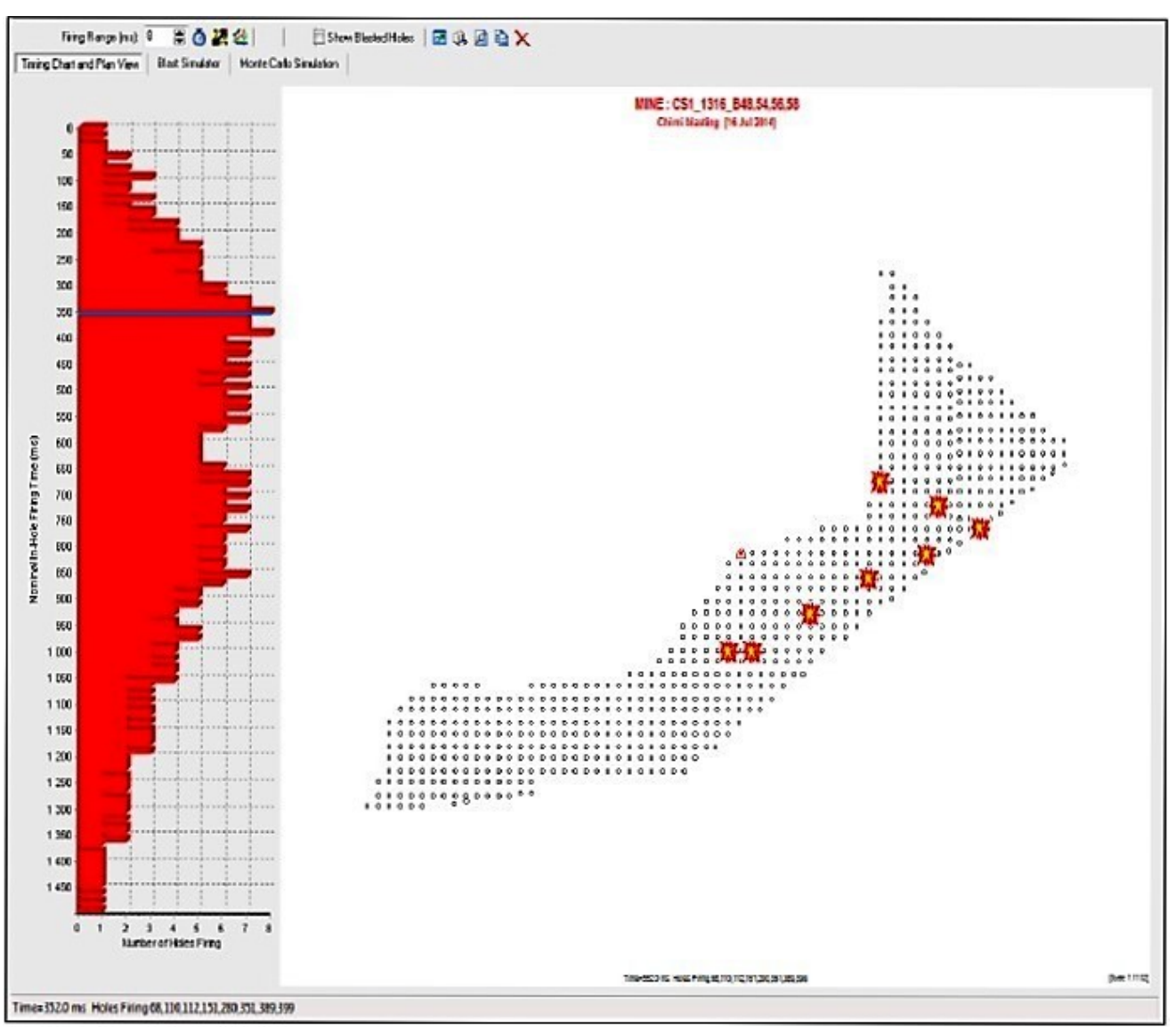

Figure 6. Timing plan for the shot and nominal delays.

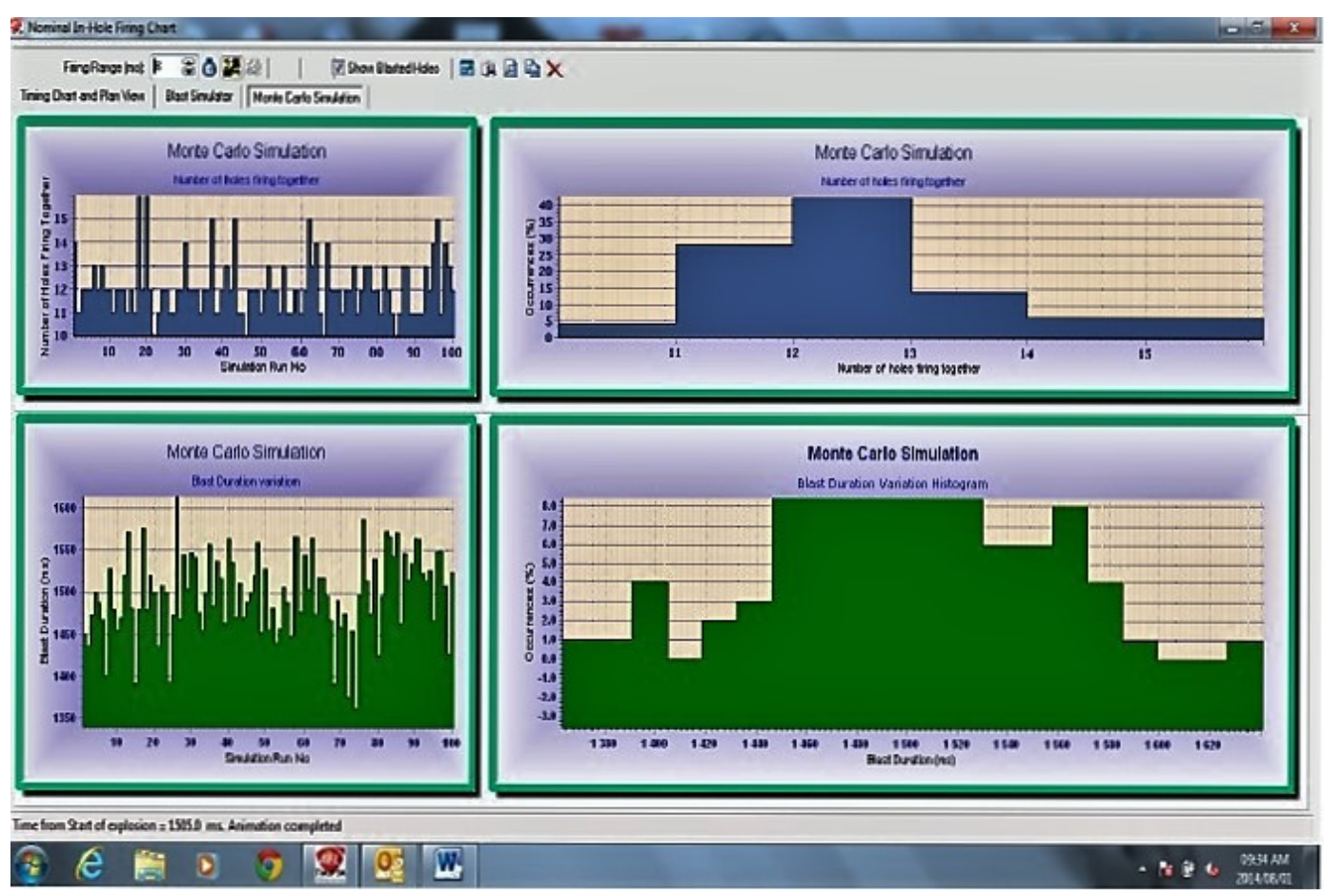

Figure 7. Simulation of maximum number of delays. 
Table 4. Seismograph results.

\begin{tabular}{|c|c|c|c|c|}
\hline Seismograph & Radial (mm/sec) & Vertical (mm/sec) & Transverse (mm/sec) & Vector sum (mm/sec) \\
\hline 831 & 3.81 & 4.572 & 3.81 & 5.207 \\
\hline 2317 & \multicolumn{4}{|c|}{ Did not trigger due to the levels being lower than the set trigger of $3 \mathrm{~mm} / \mathrm{s}$} \\
\hline
\end{tabular}

$$
S D=R / \sqrt[3]{Q}
$$

where

$k=1140, B=-1.6$;

$\mathrm{R}=$ Distance;

$\mathrm{Q}=$ Average charge/hole $\times$ maxmum \# of holes fired/delay.

\section{Site Constant Determination}

A simple regression was carried out of 5 data points (Figure 8) and the equations obtained where:

$$
\mathrm{PPV}=275.4(\mathrm{SD})-1.47 \text {. }
$$

From the simple regression analysis site constants $(\mathrm{k}$ and $\mathrm{B}$ ) were determined as $\mathrm{k}=275.4$ and $\mathrm{B}=-1.47$. Increasing the confidence level of the (Equation (3)), an attenuation was written on a basis of $95 \%$ confidence level, empirical factors obtained where $\mathrm{k}=1584.5$ and $\mathrm{B}=-1.5$.

$$
\mathrm{PPV}=1584.5(\mathrm{SD})-1.5
$$

\subsection{Airblast Results}

The airblast level recorded was $130 \mathrm{~dB}$ (Table 5). This was still below the level to cause any concern outside the mine boundaries. The recordings were obtained at a distance of $\pm 700 \mathrm{~m}$ from the blast and Manyama Township was at $\pm 2000 \mathrm{~m}$ away from the blast. In general, the airblast is dissipated over the distance and therefore, the Township at current levels will not be affected. Air blast level can be calculated from (Equation (5)).

$$
L_{p}=20 \log \left[\frac{p}{20 \times 10^{-9}}\right]
$$

where:

$p$ is the pressure $(\mathrm{kPa})$.

The airblast levels recorded are considered to be normal for surface blasting operations. However, improvements can be made with more effective stemming length and material. Suggested guidelines of human and structural response to different airblast levels are given below (Table 6).

Final blast results, air-blast and vibration recordings on the two machines, stood below the accepted standards are tabulated below (Table 7).

\section{Discussion}

The vibration and overpressure limits in use at Lumwana are based on the United States Bureau of Mines (USBM) standards. The USBM studied blast produced ground vibration from surface mining to assess its damage and annoyance potential, and to determine safe levels and appropriate measurement techniques. An argument might be made that the geological conditions at Lumwana may not be the same as those in the United States. The use of the USBM standards are however, still applicable. Firstly the USBM standards have been considered fit for use throughout the United States, even though the variety of geology in the United States is huge, and most defiantly contains examples of rock similar to those at Lumwana. Secondly the issue at hand is not so much the manner, or type of rock, through which the vibrations travel from the blast to the monitoring point, but the actual magnitude and frequency of the vibration that arrives at the monitoring point. The monitoring device will read exactly what the vibration is at the point it is installed, irrespective of whether the vibration waves have travelled through granite, schist, clay or any other type of rock or soil. 


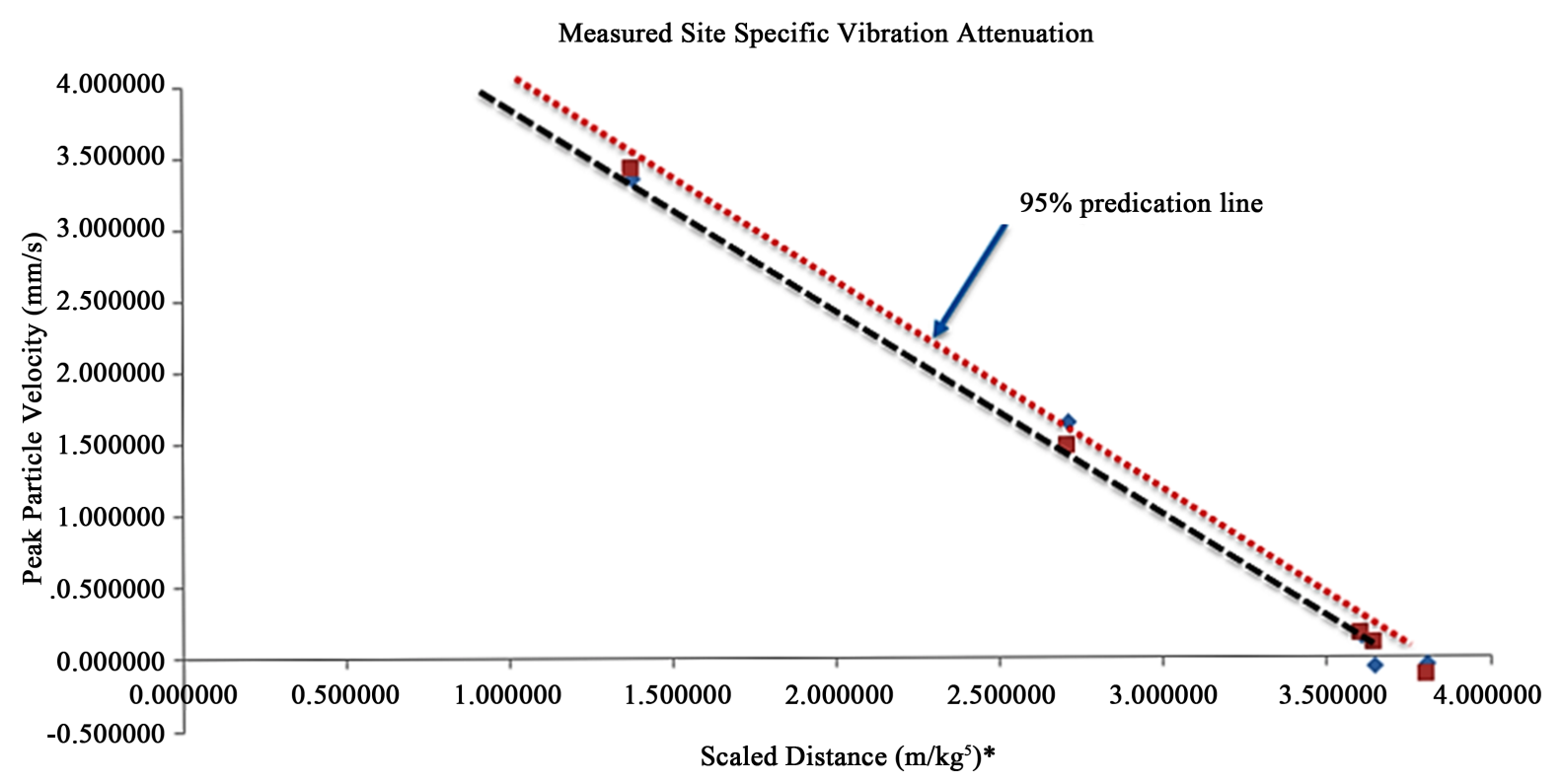

Figure 8. Vibration attenuation regression analysis. ${ }^{*}$ Scaled distance $\times 10$.

Table 5. Airblast level recorded for blast shot.

\begin{tabular}{ccc}
\hline Seismograph & Frequency $\mathbf{( H z )}$ & Pressure (dB) \\
\hline 813 & 6.1 & 130 \\
2317 & - & - \\
\hline
\end{tabular}

Table 6. Human and structural response to Airblast [13].

\begin{tabular}{|c|c|}
\hline Level & Description \\
\hline $100 \mathrm{~dB}(0.002 \mathrm{kPa})$ & Barely noticeable \\
\hline $110 \mathrm{~dB}(0.006 \mathrm{kPa})$ & Readily acceptable. Rattling of loose windows/doors/ceiling panels \\
\hline $128 \mathrm{~dB}(0.050 \mathrm{kPa})$ & $\begin{array}{l}\text { Currently acceptable by South African authorities as being a reasonable level for public concern. } \\
\text { No more than } 10 \% \text { of measurements should exceed this value) }\end{array}$ \\
\hline $134 \mathrm{~dB}(0.100 \mathrm{kPa})$ & $\begin{array}{l}\text { - Limit is } 133 \mathrm{~dB} \text { if lower frequency limit of the instrument is } 2 \mathrm{~Hz} \text {. } \\
\text { (No measurements should exceed this value outside of the mining boundaries.) } \\
\text {-Good Highveld thunderstorm }\end{array}$ \\
\hline $140 \mathrm{~dB}(0.200 \mathrm{kPa})$ & $\begin{array}{l}\text { - Exceed by strong wind gusts } \\
\text { - Poorly mounted pictures, rattling of objects on shelves/display units, potential for these to fall }\end{array}$ \\
\hline $170 \mathrm{~dB}(6.3 \mathrm{kPa})$ & Will break a well mounted window \\
\hline
\end{tabular}

Table 7. Blast results.

\begin{tabular}{|c|c|c|c|c|c|}
\hline Seismograph & Radial (mm/sec) & Vertical (mm/sec) & Transverse (mm/sec) & Vector sum (mm/sec) & Airblast (dB) \\
\hline 831 & 3.81 & 4.572 & 3.81 & 5.207 & 130 \\
\hline 2317 & \multicolumn{5}{|c|}{ Did not trigger due to the levels being lower than the set trigger of $3 \mathrm{~mm} / \mathrm{s}$} \\
\hline
\end{tabular}

In the absence of sufficient data, a regression analysis was conducted on five data points. The analysis carried out using the small sample of data available from the machines for that blast only, showed constant " $\mathrm{k}$ " calculated at 273, this is near the typical value for a free-faced hard or highly structured rock (500). Constant "B” was 
estimated at -1.47 which is close to the USMB suggested typical value of -1.6 .

The levels recorded by seismograph 831 were well below accepted industry standards and the guidelines AEL use of $10 \mathrm{~mm} / \mathrm{s}$ and a maximum of $134 \mathrm{~dB}$ at the mine boundary. The larger the charge mass, the higher the amplitude of the ground vibration. The charge mass can be limited by timing blasts so that holes fire one at a time or by reducing the blast hole diameters. These are practical measures that have a marked influence on vibration amplitudes. It is a good practice to check the timing design on a computer simulation program to make sure that the design gives a single hole firing. However a simulation on the maximum mass per delay using the AEL tie-up software and the USBM formulae indicated that the predicted PPV at $2000 \mathrm{~m}$ would not exceed 2.46 $\mathrm{mm} / \mathrm{s}$, which is well below the normal background levels.

The main areas of both environmental and geotechnical concerns were buildings response to forced vibration of foundations in Manyama, pit wall and slope stability. However, there was no apparent direct study on whether the soil adobe content was among other factors impacting the house structures. The test pit logs and soil tests carried out classified the soils at Manyama as clayey sand, sandy soil with a lesser clay content. These are not Adobe soils, Adobe soils are high in clay content. It was very clear that the quality of construction of the houses at Manyama is very poor. None of the houses had a concrete foundation, just burnt brick walls set in the ground. As such there is no resistance to natural movement caused by seasonal moisture changes. Even with zero vibration the house will be prone to cracking over time by virtue of having such poor foundation. There is no rationale to lower charge weight of individual holes based on the soil profile found at Manyama. Sandy soils are typical for this area of NW province. The vibration monitoring results predicted at Manyama are low, much lower than the threshold of $5 \mathrm{~mm} / \mathrm{sec}$ used at Lumwana.

\section{Conclusions}

The airblast and ground vibration levels monitored and recorded were considered to be normal for surface blasting operations. Improvements can be made with more effective stemming length and quality to further reduce the airblast. The mass per delay simulated and calculated ranged between a nominal of $1568 \mathrm{~kg} /$ delay to a maximum of $2352 \mathrm{~kg} /$ delay. The readings would indicate that there would be no impact on any potential neighbouring communities, outside the mine boundary, as Manyama Township was at $\pm 2000 \mathrm{~m}$ away from the blast, and the peak particle velocity was predicted at $2.46 \mathrm{~mm} / \mathrm{s}$. To avoid potential problems, it is clearly preferable to blast at the noisier times of the day.

It is recommended that more monitoring be conducted to confirm these results as only one blast was monitored. To further assist with predictions of ground vibration levels at $2000 \mathrm{~m}$ away from the blast, site characteristics are required that can only be calculated from two or more PPV recordings and no Blasts should be fired on Sundays or public holidays, unless approval is obtained.

\section{Acknowledgements}

The authors wish to thank the entire Lumwana Mining Company technical staff. This work was supported in part by the Lumwana Mining Company (LMC) technical services department and the University of Science and Technology Beijing.

\section{References}

[1] Akande, J.M. and Awojobi, D. (2005) Assessment of Environmental Impact of Exploitation of Granite Deposit in Iiorin, Nigeria. Journal of Science, 10, 4888-4900.

[2] Singh, P.K., Vogt, W., Singh, R.B. and Singh, D.P. (1996) Blasting Side Effects-Investigations in an Opencast Coal Mine in India. International Journal of Surface Mining Reclamation and Environment, 10, 155-159. http://dx.doi.org/10.1080/09208119608964824

[3] Mohamed, M. (2010) Vibration Control, Vibration Control. In: Lallart, M., Ed., InTech. http://www.intechopen.com/books/vibration-control/vibration-control.

[4] Akande, J.M., Aladejare, A.E. and Lawal, A.I. (2014) Evaluation of the Environmental Impacts of Blasting in Okorusu Fluorspar Mine, Namibia. International Journal of Engineering and Technology, 4.

[5] Rudenko, D. (2002) An Analytical Approach for Diagnosing and Solving Blasting Complaints. The Journal of Explosives Engineering, 19, 36-41. 
[6] Valdivia, C., Vega, M., Scherpenisse, C.R. and Adamson, W.R. (2003) Vibration Simulation Method to Control Stability in the Northeast Corner of Escondida Mine. International Journal of Rock Fragmentation by Blasting, 7, 63-78. http://dx.doi.org/10.1076/frag.7.2.63.15897

[7] Roşia Montană Gold Corporation. Report on Environmental Impact Assessment Study Noise and Vibration Management Plan.

[8] Peter, P. (2015) Blast Vibration and Noise Managment Plan. Barrick Lumwana, Solwezi.

[9] Stroud, R. (2010) 2010 Life of Mine Plan Malundwe/Kanga and Chimiwungo Pits. Optiro Pty Limited, Perth.

[10] Richards, M. and Nisbet, B. (2003) The Geology of the Mwombezhi Dome and Malundwe and Chimiwungo Copper Deposits Northwest Province Zambia Equinox: Kitwe.

[11] Cailteux, J.L.H., Kampunzu, A.B., Lerouge, C., Kaputo, A.K. and Milesi, J.P. (2005) Genesis of Sediment-Hosted Stratiform Copper-Cobalt Deposits, Central African Copperbelt. Journal of African Earth Sciences, 42, 134-158. http://dx.doi.org/10.1016/j.jafrearsci.2005.08.001

[12] Faramarzi Farhad, E.F. (2014) Simultaneous Investigation of Blast Induced Ground Vibration and Airblast Effects on Safety Level of Structures and Human in Surface Blasting. International Journal of Mining Science and Technology, 663-669. http://dx.doi.org/10.1016/j.ijmst.2014.07.006

[13] Goncalves, C.G. and Tose, S.J. (2009) Shaft Sinking with Electronic Detonators at the Gautrain Rapid Rail Project. Shaft Sinking and Mining Contractors Conference. The Southern African Institute of Mining and Metallurgy, 1-10.

[14] Nobel, D. (2010) Blasting and Explosives Quick Reference Guide. Dyno Nobel Asia Pacific Pty Limited, Kalgoorlie. 